\title{
Distinct Alteration in Brain Endothelin A and B Receptor Characteristics Following Focal Cerebral Ischemia in Rats
}

Authors

Affiliation

\author{
S. Bhalla, M. G. Leonard, S. Briyal, A. Gulati
}

Chicago College of Pharmacy, Midwestern University, Downers Grove, United States

\author{
Key words \\ - cerebral ischemia \\ - endothelin \\ receptor binding \\ - $\mathrm{ET}_{\mathrm{A}}$ receptors \\ - $\mathrm{ET}_{\mathrm{B}}$ receptors
}

received 25.03.2015

accepted 11.08.2015

\section{Bibliography}

DOI http://dx.doi.org/ 10.1055/s-0035-1559779

Published online:

September 23, 2015

Drug Res 2016;

66: 189-195

(c) Georg Thieme Verlag KG

Stuttgart · New York

ISSN 2194-9379

\section{Correspondence}

\section{A. Gulati, MD, PhD}

Associate Dean and Professor Chicago College of Pharmacy Midwestern University $55531^{\text {st }}$ St.

Downers Grove IL 60515-1235

Tel.: + 1/630/9716417

Fax: + 1/630/971 6097

AGULAT@midwestern.edu

\section{Abstract}

$\nabla$

Manipulation of the central endothelin (ET) system via either $\mathrm{ET}_{\mathrm{A}}$ antagonists or $\mathrm{ET}_{\mathrm{B}}$ agonists following experimental cerebral ischemia has been shown to be beneficial in previous experimental studies. In order to further explore the involvement of these receptors in cerebral ischemia, we determined changes in binding affinity $\left(\mathrm{K}_{\mathrm{d}}\right)$ and density $\left(\mathrm{B}_{\max }\right)$ of $\mathrm{ET}_{\mathrm{A}}$ and $\mathrm{ET}_{\mathrm{B}}$ receptors in the rat brain at $24 \mathrm{~h}$ and 1 week following middle cerebral artery occlusion (MCAO). Rats subject to MCAO exhibited significant neurological and motor function deficit as well as large infarct volumes $\left(126.41 \pm 40.12\right.$ and $152.82 \pm 21.67 \mathrm{~mm}^{3}$ on days 1 and 7 , respectively). $B_{\max }$ increased $(\mathrm{P}<0.01)$ and $\mathrm{K}_{\mathrm{d}}$ decrease $_{\mathrm{d}}(\mathrm{P}<0.01)$ for $\mathrm{ET}_{\mathrm{A}}$ receptors in the infarcted right cerebral hemi-

\section{Introduction}

$\nabla$

Stroke is a leading cause of death and long-term disability worldwide. In addition to a loss of mental and motor capabilities, multiple deleterious pathways are initiated within the brain tissue itself. Coincident with neuronal apoptosis, there is a rise in oxidative stress as well as an increase in the expression of endothelin $\mathrm{A}\left(\mathrm{ET}_{\mathrm{A}}\right)$ receptor and its endogenous ligand ET-1 [1,2].

Endothelin (ET) has been implicated in numerous physiological and pathological phenomena within the body. Acting upon 2 distinct receptors, $\mathrm{ET}_{\mathrm{A}}$ and $\mathrm{ET}_{\mathrm{B}}$, ET influences a range of processes from regulation of blood pressure to neurotransmitters [3-6]. ET receptors are widespread throughout the body, including the brain, where they are located on neurons and glial cells as well as the cerebovasculature [7]. Although previous studies focused on selectively antagonizing the $\mathrm{ET}_{\mathrm{A}}$ receptor following cerebral ischemia have led to some promising results, non-selective antagonism of both $\mathrm{ET}_{\mathrm{A}}$ and sphere compared to sham $24 \mathrm{~h}$ post MCAO. However, after 7 days of MCAO, $\mathrm{B}_{\max }$ of $\mathrm{ET}_{\mathrm{A}}$ receptors was similar, while $K_{d}$ in the infarcted hemisphere increased $(\mathrm{P}<0.05)$ compared to sham. Binding characteristics for brain $\mathrm{ET}_{\mathrm{B}}$ receptors were not altered $24 \mathrm{~h}$ post MCAO. However, 7days following MCAO, there was a significant decrease $(\mathrm{P}<0.001)$ in $\mathrm{K}_{d}$ values and an increase $(\mathrm{P}<0.001)$ in $\mathrm{B}_{\max }$ values for $\mathrm{ET}_{\mathrm{B}}$ receptors in the ischemic cerebral hemisphere. The initial increase in $\mathrm{ET}_{\mathrm{A}}$ receptors is damaging and may be aggravating cerebral ischemia due to its vasoconstrictive actions. On the other hand, since $\mathrm{ET}_{\mathrm{B}}$ receptors have been shown to enhance brain angiogenesis, it is possible that an increase in binding characteristics of these receptors is part of a natural defense mechanism to repair the ischemic brain.

$\mathrm{ET}_{\mathrm{B}}$ receptors has not been as effective and has led to conflicting reports [8-12].

Initial studies in our laboratory demonstrated that selective $\mathrm{ET}_{\mathrm{B}}$ receptor stimulation via IRL1620 significantly improved neurological and motor function while drastically decreasing infarct volume at both $24 \mathrm{~h}$ and 7 days following permanent middle cerebral artery occlusion (MCAO) in rats [2,13]. These studies also demonstrated that MCAO rats treated with IRL-1620 presented with reduced oxidative stress as well as increased angiogenesis and neurogenesis as compared with the vehicle-treated animals, indicating a further neuroprotective and neuroreparatory role for $\mathrm{ET}_{\mathrm{B}}$ receptors following cerebral ischemia [14].

While these initial studies have clearly demonstrated that the ET system is involved in the pathophysiology of ischemic stroke, it is of interest to determine how the binding characteristics of the ET receptors are altered at different stages of cerebral ischemia in order to optimize poten- 
tial treatments. Therefore, the purpose of this study was determine the effects of permanent MCAO on the binding characteristics of both $\mathrm{ET}_{\mathrm{A}}$ and $\mathrm{ET}_{\mathrm{B}}$ receptors in the rat brain during the acute and sub-acute phases of cerebral ischemia.

\section{Methods and Materials}

$\nabla$

Animals

Male Sprague Dawley rats weighing 250-300g were used. The animals were housed 2 per cage with controlled temperature ( $23 \pm 1^{\circ}$ Celsius), humidity ( $50 \pm 10 \%$ ) and 12 -h light/dark cycle (6:00 AM to 6:00 PM). Food and water were made available ad libitum. Animal care and use of experimental procedures were approved by the Institutional Animal Care and Use Committee (IACUC) at Midwestern University.

\section{Drugs and chemicals}

$\mathrm{ET}_{\mathrm{A}}$ antagonist, BQ123 (American Peptide Co., Sunnyvale, CA), and $\mathrm{ET}_{\mathrm{B}}$ agonist, IRL1620 (Tocris Pharmaceuticals Inc., Ellisville, $\mathrm{MO}$ ), were dissolved in distilled deionized pyrogen-free water and dilutions were made in Tris buffer $(50 \mathrm{mM}, \mathrm{pH} 7.4) .\left[{ }^{125} \mathrm{I}\right]$ ET-1 (specific activity, $2200 \mathrm{Ci} / \mathrm{mmol}$, Perkin Elmer, Billerica, MA) and [ $\left.{ }^{125} \mathrm{I}\right]$ IRL1620 (specific activity, $2200 \mathrm{Ci} / \mathrm{mmol}$, Perkin Elmer, Billerica, MA) were diluted in Tris buffer (50 mM, pH 7.4).

\section{Experimental protocol}

In order to determine the progression of changes in binding characteristics of ET receptors during both acute and sub-acute phases of stroke, 2 endpoints were chosen: $24 \mathrm{~h}$ and 7 days following cerebral ischemia. Rats for each endpoint were randomly divided into 2 groups. Animals in group 1 were subject to a sham operation, and animals in group 2 were subject to MCAO. A total of 32 rats were used for this study, with $n=4$ per group, per endpoint. 2 separate groups of 16 animals each were used for either binding studies or immunoblotting. No animals were excluded from the study.

\section{Middle cerebral artery occlusion}

Permanent middle cerebral artery occlusion (MCAO) was performed according to the method of Koizumi, et al [15]. Rats were anesthetized with ketamine and xylazine. Rectal core temperature was measured with a Cole Palmer Animal Monitoring Thermometer colonic probe (Vernon Hills, IL) and maintained throughout surgery at $37 \pm 1{ }^{\circ} \mathrm{C}$ using the thermo-controlled base of the operating table. With the anesthetized rat in a secure supine position, a midline incision was made and the right common, internal, and external carotid arteries were exposed. A 4.0 monofilament nylon filament (CP Medical, Portland, OR) with a flame-rounded tip was advanced from the external carotid artery into the lumen of the internal carotid artery until resistance is felt $(\sim 20-22 \mathrm{~mm})$, indicating occlusion of the middle cerebral artery. In order to create a permanent model of cerebral ischemia, the filament was securely tied and allowed to remain in place until the end of the experiment. The incision was closed with 3.0 silk surgical sutures (Ethicon, Inc.). In sham-operated animals, the common and external right carotid arteries were exposed and the incision was sutured without touching the internal carotid artery. Rats were monitored twice daily to assess appearance, activity, and behavior. Proper and intact placement of the filament was verified in all animals at the time of sacrifice.

\section{Motor performance tests}

4 assessments were used to determine neurological and motor deficit following permanent MCAO - neurological evaluation, grip test, foot fault error test, and rota rod. Animals were subject to blinded assessments $15 \mathrm{~min}$ prior to occlusion to establish a baseline and at 1, 4 and 7 days post occlusion to determine the effects of ischemia.

\section{Neurological evaluation}

The neurological evaluation was based on a 6 point scale as described by Tatlisumak, et al. [16]. The scoring was as follows: $0=$ no deficits, 1 = failure to fully extend left forepaw, 2 = circling to the left, $3=$ paresis to the left, $4=$ no spontaneous walking, $5=$ death.

\section{Grip test}

The grip test for muscular strength consisted of a string elevated $40 \mathrm{~cm}$ above a flat surface pulled taut between 2 vertical supports spaced $50 \mathrm{~cm}$ apart. The animal was placed on the string midway between the supports and evaluated according to a 6 point scale [17]. The scoring was as follows: $0=$ falls off, 1 = hangs on by 2 forepaws, 2 =hangs on by 2 forepaws and attempts to climb on, 3 = hangs on by $3+$ paws, $4=$ hangs on by all paws plus tail, and $5=$ escapes.

\section{Foot fault error test}

Animals were placed on an elevated grid floor with a mesh size of $30 \mathrm{~mm}^{2}$ for one minute to acclimate. They were then observed for one minute and evaluated for foot fault errors (i.e. a misplaced limb falling through the grid) compared with paired steps as follows [18]:

$\%$ foot fault error $=($ number of faults/number of paired steps $) \times 100$

\section{Rota rod}

Animals were acclimated to the rotating spindle of the rota rod (Rota-Rod 47700, Ugo Basile, Italy) prior to occlusion. For acclimatization, animals were placed on the rotating spindle, set to a constant 8 rotations per minute (RPM), until they demonstrated the ability to remain on the spindle for $60 \mathrm{~s}$. Animals were then subject to a baseline test trial on the accelerating spindle (4-40 $\mathrm{RPM}$ ) over $5 \mathrm{~min}$. The acceleration trial was repeated at 1,4 and $7 \mathrm{~d}$ post occlusion, and the time (in sec) at which the animals fell off was recorded [19].

\section{Assessment of Cerebral Infarct Volume}

Animals were euthanized by decapitation at $24 \mathrm{~h}$ or one week following MCAO, and the brains were removed for assessment of infarct volume. The brains were washed in chilled saline at $4{ }^{\circ} \mathrm{C}$ for $5 \mathrm{~min}$ and then cut into $2 \mathrm{~mm}$ thick slices using a Brain Matrix (Harvard Apparatus, Holliston, MA). The sections were incubated at $37^{\circ} \mathrm{C}$ for $15 \mathrm{~min}$ in $2 \%$ 2,3,5-triphenyltetrazolium (TTC, Sigma, St. Louis, MO) dissolved in saline. The stained sections were then stored in $10 \%$ formalin at $4{ }^{\circ} \mathrm{C}$ for further analysis [20]. Infarct volume was calculated by sampling each side of the coronal sections with a digital camera (Nikon). The infarct area, outlined in white, was measured by image analysis software (Adobe Photoshop CS4). Edema was determined by taking the percent increase in size of the ischemic over the contralateral hemisphere [21]. Total infarct size is expressed as infarct volume in $\mathrm{mm}^{3}$ as the sum of infarct areas in each slice, corrected for edema. 


\section{Estimation of [ ${ }^{125}$ I]ET-1 and [125I]IRL1620 binding in the rat brain}

Rats were sacrificed and brains were quickly excised. The cerebellum was removed and remainder of the brain was washed in chilled saline. The brain was homogenized in $30 \mathrm{ml}$ of Tris- $\mathrm{HCl}$ buffer ( $50 \mathrm{mM}$, pH 7.4), using a Brinkman polytron homogenizer (setting 6 for $30 \mathrm{~s}$ ). The homogenate was centrifuged at $49.000 \times \mathrm{g}$ for $20 \mathrm{~min}$ in a refrigerated Sorvall RC-5B centrifuge $\left(4^{\circ} \mathrm{C}\right)$. The supernatant was discarded and the pellet was resuspended in $30 \mathrm{~mL}$ of Tris- $\mathrm{HCl}$ buffer and centrifuged again at $49.000 \times \mathrm{g}$ for $20 \mathrm{~min}$. The pellet was re-suspended in $30 \mathrm{~mL}$ of Tris- $\mathrm{HCl}$ buffer, homogenized again, and centrifuged for the third time at $49.000 \times g$ for $20 \mathrm{~min}$. The supernatant was discarded and the pellet used for binding studies. The amount of protein used in each tube was $40-50 \mu \mathrm{g}$. Concentration of protein in the samples was determined by using the Precision Red Assay [23].

\section{Estimation of binding to $E T_{A}$ receptors in the rat brain using [ [25 I]ET-1}

The binding of [ $\left.{ }^{125} \mathrm{I}\right] \mathrm{ET}-1$ to $\mathrm{ET}_{\mathrm{A}}$ receptors was carried out in a total volume of $0.50 \mathrm{~mL}$, which contained $0.35 \mathrm{~mL}$ of homogenate (containing $40-50 \mu \mathrm{g}$ protein) and $50 \mathrm{mM}$ Tris- $\mathrm{HCl}$ buffer ( $\mathrm{pH}$ 7.4). The final concentration of $\left.{ }^{125} \mathrm{I}\right] \mathrm{ET}-1$ was $0.5 \mathrm{nM}$ in each tube [22]. The concentration range for $\mathrm{BQ123}$, the $\mathrm{ET}_{\mathrm{A}}$ receptor antagonist, was $0-885.74 \mathrm{nM}$ and a high concentration of $15 \mu \mathrm{M}$ BQ123 was used as the displacer to determine non-specific binding. All binding assays were done in triplicate and samples were incubated at $37^{\circ} \mathrm{C}$ for $60 \mathrm{~min}$. Binding was terminated by rapidly filtering the contents of the incubation tubes through Whatman GF/B glass fiber filters under reduced pressure using a Brandell cell harvester (model M-24R). The filters were washed 3 times with $5 \mathrm{~mL}$ of $50 \mathrm{mM}$ Tris- $\mathrm{HCl}$ buffer (pH 7.4). The filters were transferred to plastic tubes and the radioactivity in all samples was determined using a Perkin Elmer gamma counter (model U5003). Total binding for $\mathrm{ET}_{\mathrm{A}}$ receptors was defined as binding observed in presence of $0-885.74 \mathrm{nM}$ of BQ123 and expressed as $\mathrm{fmol} / \mathrm{mg}$ protein (mean $\pm \mathrm{SEM}$ ). Non-specific binding was determined in presence of high concentration of BQ123 (displacer $15 \mu \mathrm{M}$ ). Specific binding was calculated by subtracting non-specific binding from total binding.

\section{Estimation of binding to $E T_{B}$ receptors in the rat brain using [125]]IRL-1620}

The binding of [ ${ }^{125}$ I]IRL1620 and [ ${ }^{125}$ I]ET- 1 was carried out in a total volume of $0.50 \mathrm{~mL}$, which contained $0.35 \mathrm{~mL}$ of homogen-

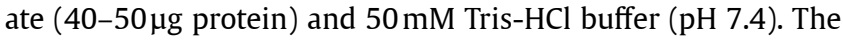
final concentration of ${ }^{125}$ I]IRL1620 was $0.39 \mathrm{nM}$ in each tube [22]. The concentration range for IRL1620 was $0-32 \mathrm{nM}$ and a high concentration of $1 \mu \mathrm{M}$ IRL1620 was used as the displacer to determine non-specific binding. All binding assays were conducted using the procedure in the subsection on $\mathrm{ET}_{\mathrm{A}}$ receptor binding. Total binding for $\mathrm{ET}_{\mathrm{B}}$ receptors was defined as binding observed in presence of 0-32 nM of IRL1620 and expressed as $\mathrm{fmol} / \mathrm{mg}$ protein (mean \pm SEM). Non-specific binding was determined in presence of high concentration of IRL1620 (displacer $1 \mu \mathrm{M}$ ). Specific binding was calculated by subtracting non-specific binding from total binding.

\section{Calculation of binding affinity $\left(K_{\mathrm{d}}\right)$ and receptor density $\left(B_{\text {max }}\right)$ in the rat brain}

The binding affinity $\left(\mathrm{K}_{\mathrm{d}}\right.$, the dissociation constant commonly used to describe the affinity between a ligand and a receptor) was determined using the following equation:

$\mathrm{K}_{\mathrm{d}}=\mathrm{K}_{\mathrm{i}}=\mathrm{IC}_{50}$-[Radioligand]

The receptor density $\left(\mathrm{B}_{\max }\right.$, the total density or concentration of receptors in the brain tissue was determined using the following equation:

$B_{\max }=\frac{\text { Top }- \text { Bottom }}{\text { Fractional Occupancy }}=\frac{\text { Top }- \text { Bottom }}{[\text { Radioligand }] /\left(K_{d}+[\text { Radioligand }]\right)}$

\section{Estimation of ET receptors in the rat brain}

$\mathrm{ET}_{\mathrm{A}}$ and $\mathrm{ET}_{\mathrm{B}}$ receptor protein levels in the infarcted brain were measured via Western blotting. Animals were decapitated at either $24 \mathrm{~h}$ or 7 days post MCAO, and the brains, sectioned into right (infarcted) and left (non-infarcted) hemispheres, were flash frozen and stored at $-80^{\circ} \mathrm{C}$. The tissue was homogenized in $10 \mathrm{x}$ $(\mathrm{w} / \mathrm{v})$ RIPA lysis buffer, and protein concentration was determined according to the Lowry method, using bovine serum albumin as standard [24]. Protein $(20 \mu \mathrm{g})$ was denatured in Laemmli sample buffer and resolved in 10\% SDS-PAGE, and then transferred onto nitrocellulose membrane. After blocking, The membranes were incubated with rabbit polyclonal anti-ET $\mathrm{E}_{\mathrm{A}}$ and anti-ET ${ }_{\mathrm{B}}$ antibodies (1:1 000) (Sigma-Aldrich, St. Louis, MO, USA) overnight at $4{ }^{\circ} \mathrm{C}$, followed by $1.5 \mathrm{~h}$ incubation with by HRP-conjugated secondary antibodies (1:2000; Cell Signaling Technology, Inc., MA) at room temperature. $\beta$-actin (1:2000; SigmaAldrich, St. Louis, MO, USA) was used as a loading control. The labeled proteins were visualized with SuperSignal West Pico Chemiluminescent Substrate (Thermo Scientific) using the Kodak Gel Logic 1500 Imaging System (Carestream Health Inc., New Haven, CT). Protein expression was analyzed using Image J (NIH) software.

Table 1 Neurological and motor deficits at baseline, Day 1, Day 4, and Day 7 following induction of cerebral ischemia. Values are expressed as Mean \pm S.E.M., $\mathrm{N}=4$ each group. ${ }^{* *} \mathrm{P}<0.001$ significant change compared to sham (control) group. ${ }^{* *} \mathrm{P}<0.01$ significant change compared to sham (control) group. ${ }^{*} \mathrm{P}<0.05$ significant change compared to sham (control) group.

\begin{tabular}{|c|c|c|c|c|c|}
\hline & Group & Baseline & Day 1 & Day 4 & Day 7 \\
\hline \multirow[t]{2}{*}{ Neurological Evaluation } & Sham & $0 \pm 0$ & $0 \pm 0$ & $0 \pm 0$ & $0 \pm 0$ \\
\hline & MCAO & $0 \pm 0$ & $2.25 \pm 0.25^{* * *}$ & $2.75 \pm 0.25^{* * *}$ & $3.00 \pm 0.41^{* * *}$ \\
\hline \multirow[t]{2}{*}{ Grip Test } & Sham & $4.25 \pm 0.25$ & $4.00 \pm 0.00$ & $4.00 \pm 0.41$ & $3.75 \pm 0.48$ \\
\hline & MCAO & $3.75 \pm 0.25$ & $1.50 \pm 0.50^{* *}$ & $1.50 \pm 0.65^{* *}$ & $0.50 \pm 0.50 * * *$ \\
\hline \multirow[t]{2}{*}{ Foot Fault Error (\%) } & Sham & $4.24 \pm 1.16$ & $4.55 \pm 0.80$ & $3.09 \pm 1.50$ & $3.50 \pm 2.36$ \\
\hline & MCAO & $5.42 \pm 2.08$ & $47.68 \pm 11.19^{* * *}$ & $43.54 \pm 6.53 * * *$ & $35.27 \pm 6.71^{* *}$ \\
\hline \multirow[t]{2}{*}{ Rota Rod Duration (sec) } & Sham & $103.25 \pm 11.10$ & $145.25 \pm 10.70$ & $146.25 \pm 11.99$ & $124.25 \pm 13.62$ \\
\hline & MCAO & $111.75 \pm 6.14$ & $26.25 \pm 9.94^{* * *}$ & $56.50 \pm 26.61^{* *}$ & $47.50 \pm 28.99^{*}$ \\
\hline
\end{tabular}




\section{Statistical analysis}

Statistical analysis of binding affinity $\left(\mathrm{K}_{\mathrm{d}}\right)$ and receptor density $\left(B_{\max }\right)$ was conducted using GraphPad Prism version 5.00 for Windows (GraphPad Software, San Diego, CA, USA). Statistical differences between groups for receptor binding studies were analyzed using Students t-test. Statistical differences between groups for behavioral studies were analyzed using a one-way ANOVA followed by post-hoc test (Bonferroni's Test). A level of $\mathrm{P}<0.05$ was considered significant.

\section{Results}

\section{Effect of MCAO on neurological and motor function}

The induction of permanent cerebral ischemia resulted in a marked neurological and motor function deficit ( $\odot$ Table 1 ). Animals undergoing right MCAO presented with paresis and weakness of their left limbs lasting up to 7 days following ischemia as measured by the neurological and grip tests. Similarly, motor function and coordination were impaired in animals following MCAO as demonstrated by an over $35 \%$ foot fault error $(\mathrm{P}<0.01)$ and a decreased ability to remain on the rotating spindle of the rota $\operatorname{rod}(\mathrm{P}<0.05)$.

\section{Infarct Volume}

Animals subject to MCAO presented with significant infarct volumes as detected by TTC staining ( $\odot$ Fig. 1). After $24 \mathrm{~h}$, occluded animals had infarct volumes of $126.41 \pm 40.12 \mathrm{~mm}^{3}$. The size of the infarct increased in animals subject to 7 days of permanent MCAO, with volumes of $152.82 \pm 21.67 \mathrm{~mm}^{3}$.

\section{Effect of MCAO on $E T_{A}$ receptor binding characteristics}

After $24 \mathrm{~h}$ of permanent cerebral ischemia, the density $\left(B_{\max }\right)$ of $\mathrm{ET}_{\mathrm{A}}$ receptors increased significantly in the infarcted hemisphere ( $\odot$ Fig. 2a; $\mathrm{P}<0.01$ ). At the same time, the $\mathrm{K}_{\mathrm{d}}$ for $\mathrm{ET}_{\mathrm{A}}$ receptors decreased from $16.38 \pm 2.15 \mathrm{nM}$ to $7.69 \pm 1.05 \mathrm{nM}(\mathrm{P}<0.01)$ in the infarcted hemisphere of the sham and MCAO groups, respectively. Conversely, by day 7 of permanent MCAO, the density of $\mathrm{ET}_{\mathrm{A}}$ receptors had returned to normal levels, while the $\mathrm{K}_{\mathrm{d}}$ was increased ( $\odot$ Fig. $\mathbf{2 b} ; \mathrm{P}<0.05$ ) in the infarcted hemisphere of occluded animals as compared to sham.

\section{Effect of MCAO on $\mathrm{ET}_{B}$ receptor binding characteristics}

There was no significant difference in either $\mathrm{B}_{\max }$ or $\mathrm{K}_{\mathrm{d}}$ of $\mathrm{ET}_{\mathrm{B}}$ receptors after $24 \mathrm{~h}$ of permanent cerebral ischemia ( $\bullet$ Fig. 3a). By 7 days post MCAO, however, $\mathrm{B}_{\max }$ for $\mathrm{ET}_{\mathrm{B}}$ receptors in the

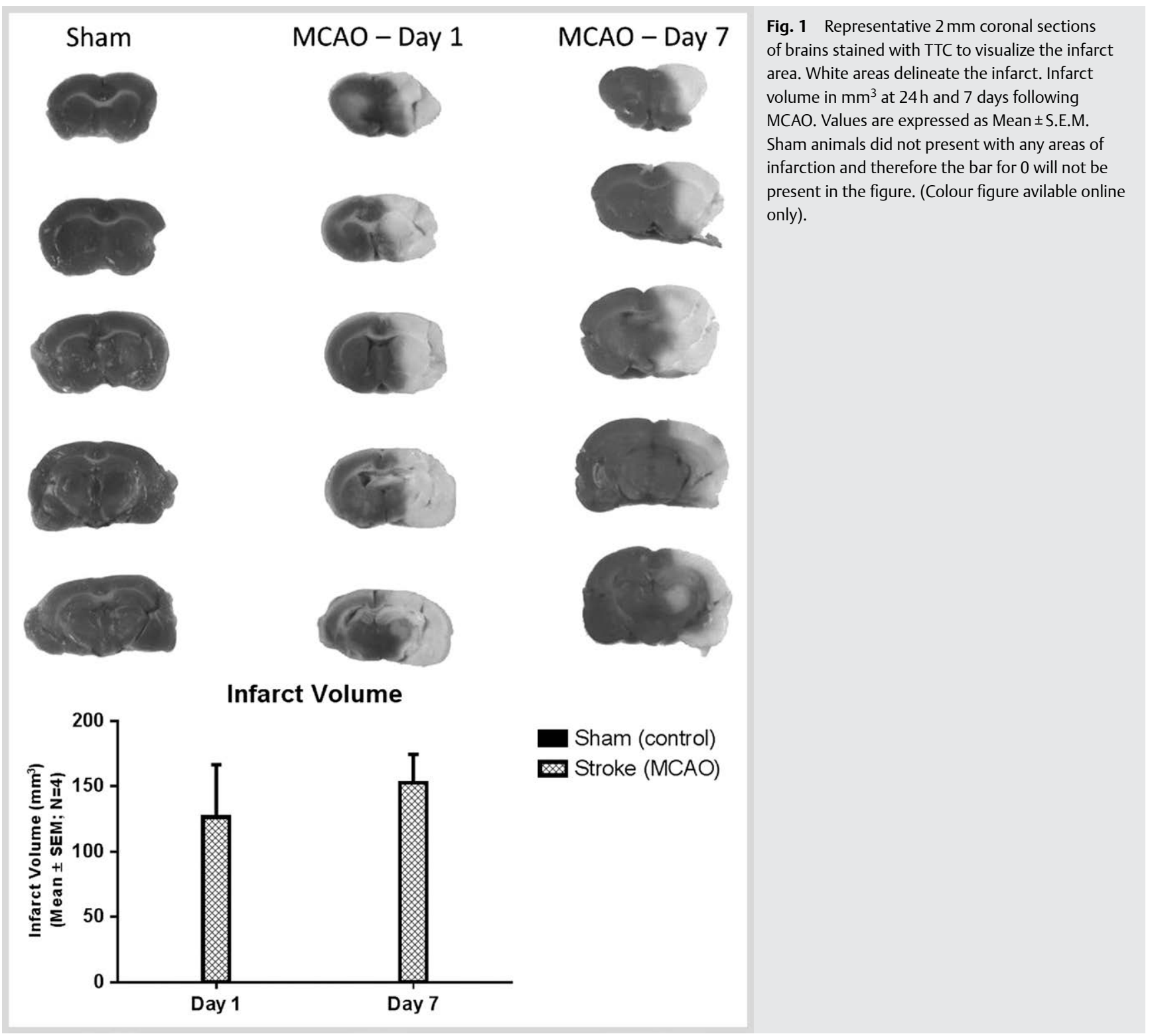



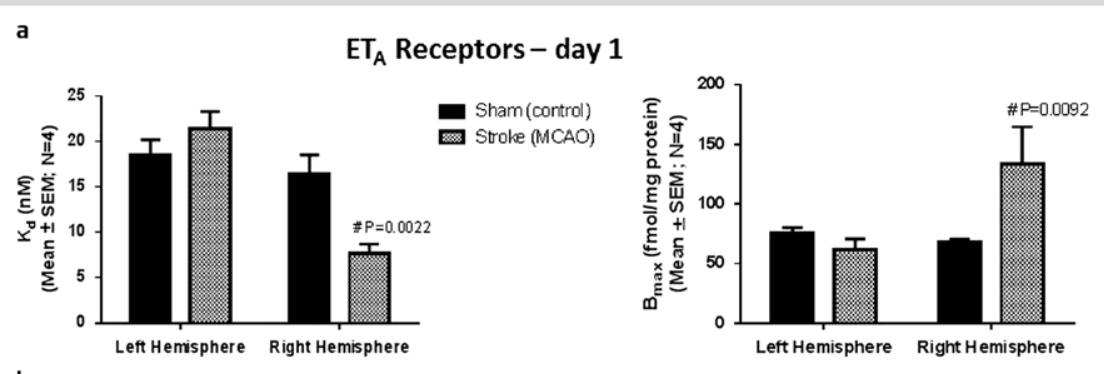

Fig. 2 Binding affinity $\left(K_{d}\right)$ and receptor density $\left(B_{\max }\right)$ of $E T_{A}$ receptors in the left and right cerebral hemisphere in male Sprague Dawley rats a 24-h and $\mathbf{b} 7$ days following MCAO. Values are expressed as Mean \pm S.E.M, $N=4$ each group. $\# P<0.01$ significant change compared to sham (control) group.

b

$\mathrm{ET}_{\mathrm{A}}$ Receptors - day 7
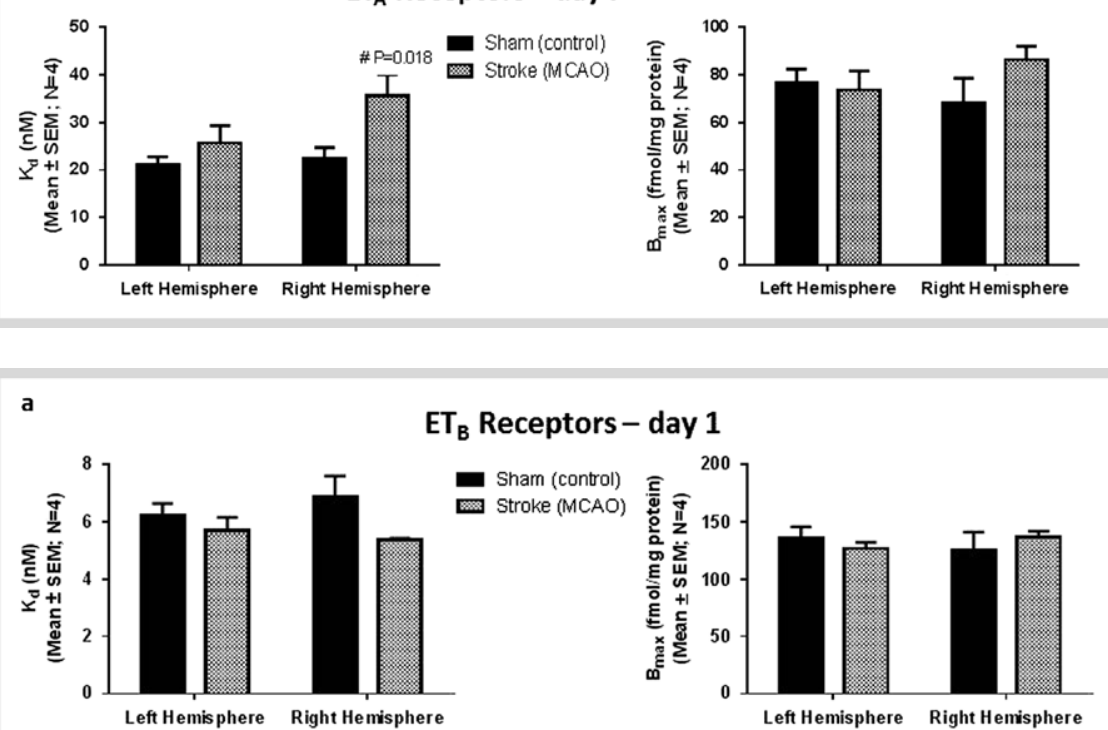

Fig. 3 Binding affinity $\left(K_{d}\right)$ and receptor density $\left(B_{\max }\right)$ of $\mathrm{ET}_{B}$ receptors in the left and right cerebral hemisphere in male Sprague Dawley rats a 24-h and $\mathbf{b} 7$ days following MCAO. Values are expressed as Mean \pm S.E.M, $N=4$ each group. ${ }^{*} \mathrm{P}<0.05$ significant change compared to sham (control) group. $\# \mathrm{P}<0.0001$ significant change compared to stroke (MCAO) left hemisphere.

b
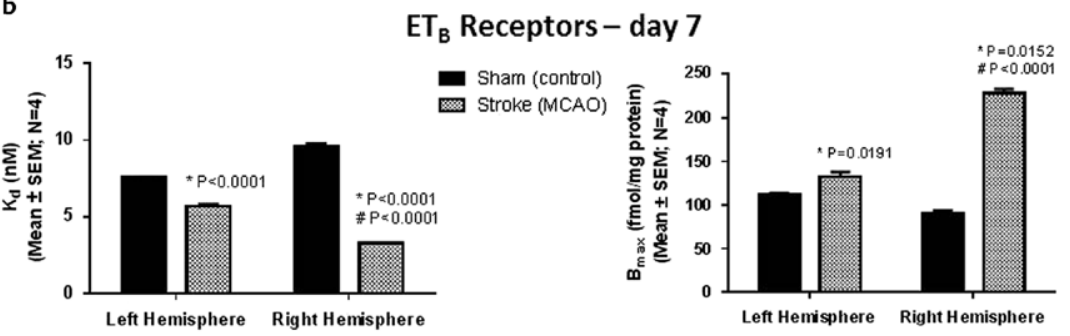

infarcted hemisphere of the stroked animals was significantly higher ( $\odot$ Fig. 3b; $P<0.001$ ) than that of sham animals. $K_{d}$ in the infarcted hemisphere was $3.30 \pm 0.03 \mathrm{nM}$, significantly lower than $9.60 \pm 0.20 \mathrm{nM}$ of the comparable hemisphere in the sham group $(\mathrm{P}<0.001)$. Interestingly, the contralateral hemisphere of MCAO animals 7 days following occlusion showed a similar, albeit lesser pattern in both density and binding as the ipsilateral hemisphere with a rise in $B_{\max }(P<0.05)$ and a decrease in $K_{d}$ $(\mathrm{P}<0.001)$ as compared to sham. The changes in the right hemisphere (ischemic) were highly significant compared to left hemisphere (non-ischemic) of the rats with MCAO.

\section{Effect of MCAO on ET receptor protein expression}

Protein expression of brain $\mathrm{ET}_{\mathrm{A}}$ receptors was significantly increased in the infarcted hemisphere at $24 \mathrm{~h}$ after permanent MCAO ( $\odot$ Fig. 4; P<0.001). By 7 days of permanent cerebral ischemia, however, $\mathrm{ET}_{\mathrm{A}}$ receptor expression in the infarcted hemisphere returned to normal levels, showing no significant difference when compared to either the sham group or the contralateral hemisphere of the stroked group. Brain $\mathrm{ET}_{\mathrm{B}}$ receptor protein expression did not vary significantly between either the sham and stroked animals or the infarcted/contralateral hemispheres at both $24 \mathrm{~h}$ and 7 days post MCAO (० Fig. 5).

\section{Discussion}

$\nabla$

This is the first study to show how the binding characteristics of ET receptors alter over time in a brain subject to ischemia. Specifically, the density and binding affinity of $\mathrm{ET}_{\mathrm{A}}$ receptors are high in the infarcted areas of the brain at $24 \mathrm{~h}$ post ischemia, while $\mathrm{ET}_{\mathrm{B}}$ receptor binding characteristics are unaltered compared to sham. After 7 days of permanent ischemia, however, $\mathrm{ET}_{\mathrm{A}}$ receptor binding characteristics are similar to sham, whereas $\mathrm{ET}_{\mathrm{B}}$ receptor density and binding affinity significantly increase. These differences in the pathophysiology of the central ET system at various stages of ischemic stroke may help to optimize novel treatments for this disease.

In the present study, we examined the binding characteristics of both $\mathrm{ET}_{\mathrm{A}}$ and $\mathrm{ET}_{\mathrm{B}}$ receptors in the brain during both the acute (24h) and sub-acute (7 days) stages of ischemic stroke. Whereas the acute phase is hallmarked by a strong oxidative stress reaction, the sub-acute phase is characterized by microvascular damage, inflammation and a breakdown in the blood brain barrier, resulting in significant cerebral edema $[25,26]$. During this stage, the brain also begins its long road to recovery, initiating angiogenesis, neurogenesis and neuroblast migration towards the ischemic boundary [27]. It has previously been reported that 

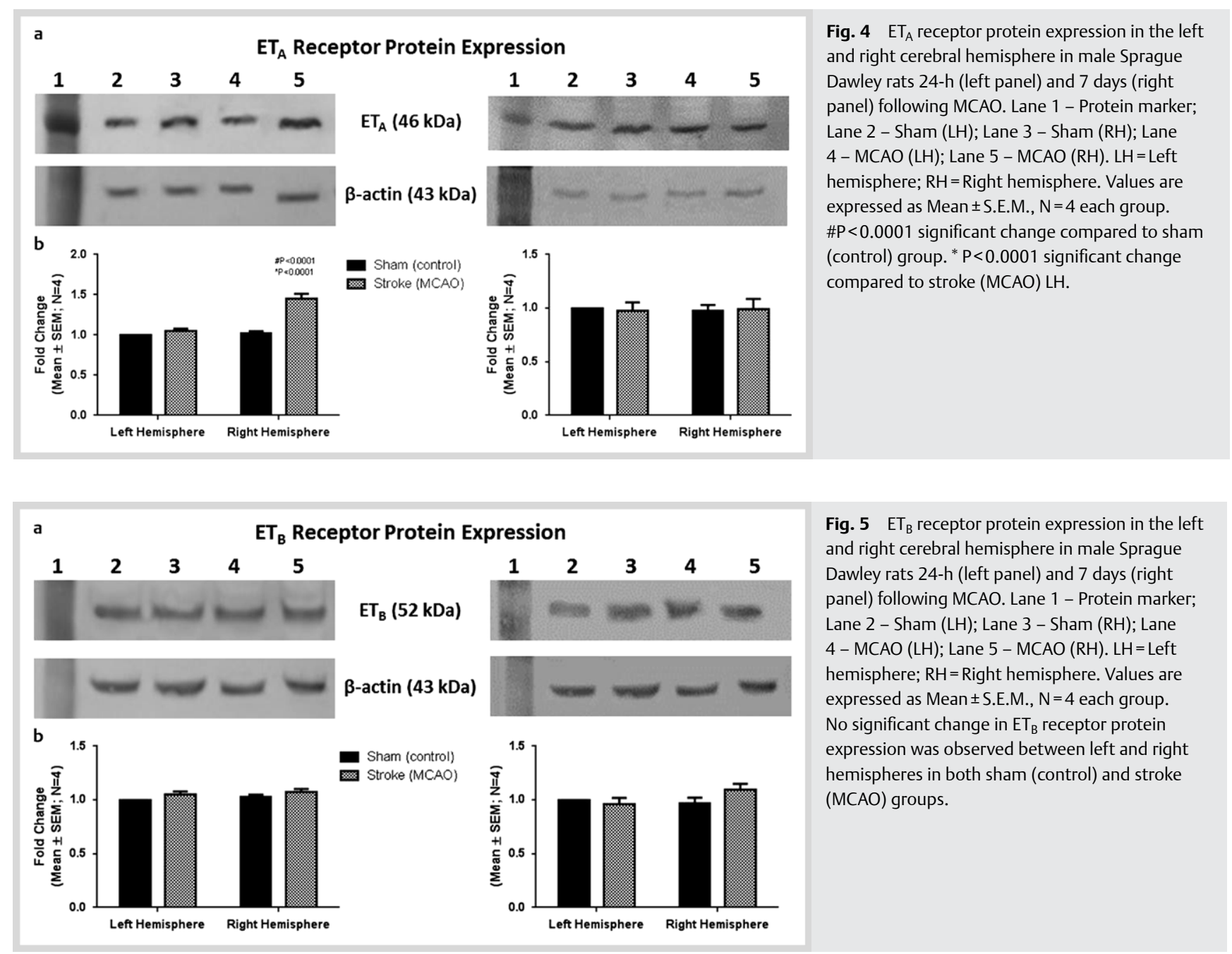

ET-1 levels are elevated during the first $24 \mathrm{~h}$ following an ischemic attack, correlating with the relative size of the infarct [1]. Here, we show that the $B_{\max }$ increases while $K_{d}$ decreases for $\mathrm{ET}_{\mathrm{A}}$ receptors in the infarcted hemisphere during the first $24 \mathrm{~h}$ following MCAO in rats. Additionally, we demonstrate that $\mathrm{ET}_{\mathrm{A}}$ receptor protein expression is significantly elevated after the initial $24 \mathrm{~h}$ of cerebral ischemia. Changes in $\mathrm{ET}_{\mathrm{A}}$ receptor characteristics in the first $24 \mathrm{~h}$ after ischemia along with an increase in ET-1 may lead to severe vasoconstriction of cerebral blood vessels. One week after infarct, $\mathrm{ET}_{\mathrm{A}}$ receptor density returns to normal, with lower binding affinity and a normal protein expression. High levels of ET-1 and its subsequent stimulation of $\mathrm{ET}_{\mathrm{A}}$ receptors have been implicated in delayed hypoperfusion, excitotoxicity, blood brain barrier disruption and inflammation following cerebral ischemia [28]. For this reason, several studies have been conducted using $\mathrm{ET}_{\mathrm{A}}$ antagonists as a treatment for ischemic stroke in animal models $[9,12,21]$. Although $\mathrm{ET}_{\mathrm{A}}$ antagonists have proven relatively beneficial in these models, combination $\mathrm{ET}_{\mathrm{A}}$ and $\mathrm{ET}_{\mathrm{B}}$ antagonists have not [8]. These results point to the differing roles which $\mathrm{ET}_{\mathrm{A}}$ and $\mathrm{ET}_{\mathrm{B}}$ receptors may play in the pathogenesis and/or recovery of cerebral ischemia.

There was no alteration in the binding characteristics of $\mathrm{ET}_{\mathrm{B}}$ receptors in the rat brain at $24 \mathrm{~h}$ after cerebral ischemia as compared to sham group. After 7 days, however, $B_{\max }$ was increased and $\mathrm{K}_{\mathrm{d}}$ was decreased for $\mathrm{ET}_{\mathrm{B}}$ receptors, indicating an increase in the density and binding affinity for these receptors during the sub-acute phase of stroke. A small but significant increase in
$\mathrm{B}_{\max }$ and decrease in $\mathrm{K}_{\mathrm{d}}$ values was observed in the contralateral hemisphere. Minor but significant changes observed on the contralateral side could be due to the mild hypoxia from surgery involving manipulation of the common carotid artery to produce an occlusion of the middle cerebral artery. The changes in the ischemic hemisphere were highly significant compared to non-ischemic hemisphere. This indicates that an increase in the density and affinity of $\mathrm{ET}_{\mathrm{B}}$ receptors is specifically due to ischemia and could play an important role in attenuating damage to the brain or assisting in neurovascular recovery. Interestingly, however, we did not observe any change in $\mathrm{ET}_{\mathrm{B}}$ receptor protein expression as measured by Western blot at either $24 \mathrm{~h}$ or 7 days post MCAO. While these findings seemingly contradict the results of the binding characteristics, they do coincide with previous reports on $\mathrm{ET}_{\mathrm{B}}$ protein expression following permanent cerebral ischemia $[2,13,14]$. A major difference between binding studies and Western blot analysis is the use of $\mathrm{ET}_{\mathrm{B}}$ agonist, IRL1620. In binding studies, we used IRI1620 to label the receptors and also to displace the radiolabeled IRl1620 from its specific receptors. On the other hand Western blots do not involve use of any $\mathrm{ET}_{\mathrm{B}}$ agonists, and specific antibodies are used to determine the expression of $\mathrm{ET}_{\mathrm{B}}$ receptors.

The lack of change in $\mathrm{ET}_{\mathrm{B}}$ receptor expression in the present Western blot studies can be explained based on the fact that there is no explicit stimulation of the $\mathrm{ET}_{\mathrm{B}}$ receptors by IRL 1620 . $\mathrm{ET}_{\mathrm{A}}$ receptors are outer membrane bound, while $\mathrm{ET}_{\mathrm{B}}$ receptors are localized to both the outer membrane and intracellular com- 
partments [29]. $\mathrm{ET}_{\mathrm{B}}$ receptors also desensitize faster than $\mathrm{ET}_{\mathrm{A}}$ receptors [29]. Internal $\mathrm{ET}_{\mathrm{B}}$ receptors are recycled to the cell membrane in the presence of $\mathrm{ET}_{\mathrm{B}}$ agonist, IRL1620; therefore, changes in $\mathrm{ET}_{\mathrm{B}}$ receptors can be detected in receptor binding studies when IRL1620 is used as a ligand. In the absence of IRL1620 (such as in the Western blotting studies), $\mathrm{ET}_{\mathrm{B}}$ receptors remain in the intracellular compartments. It is possible that the internal receptors are not fully converted to $\mathrm{ET}_{\mathrm{B}}$ receptors until being selectively stimulated by a specific $\mathrm{ET}_{\mathrm{B}}$ agonist. Similar findings have been previously observed where upon stimulation of $\mathrm{ET}_{\mathrm{B}}$ receptors by IRL1620, the expression of $\mathrm{ET}_{\mathrm{B}}$ receptors is enhanced as detected in Western blot studies [13]. Therefore, it appears that recycling of $\mathrm{ET}_{\mathrm{B}}$ receptors may be responsible for the differences observed in $\mathrm{ET}_{\mathrm{B}}$ receptors in receptor expression and receptor binding studies.

Previous studies conducted in our laboratory have demonstrated that selective stimulation of $\mathrm{ET}_{\mathrm{B}}$ receptors via agonist, IRL-1620, leads to a significant reduction in infarct volume, oxidative stress and neurological and motor deficits during both the acute and sub-acute stages of cerebral ischemia in rats $[2,13]$. During the sub-acute phase of ischemic stroke, stimulation of $\mathrm{ET}_{\mathrm{B}}$ receptors resulted in an increase in vascular and neuronal growth factors, highlighting the beneficial role these receptors may play in neurovascular repair and recovery following cerebral ischemia [14]. These studies, combined with the present results, indicate that selective $\mathrm{ET}_{\mathrm{B}}$ receptor stimulation may be a novel therapeutic tool in the treatment of ischemic stroke.

\section{Conclusions}

\section{$\nabla$}

This is the first study demonstrating that the binding characteristics of ET receptors are altered during the acute and sub-acute stages of cerebral ischemia. Specifically, the binding affinity and density of $\mathrm{ET}_{\mathrm{A}}$ receptors are high following the first $24 \mathrm{~h}$ of ischemia, but return to normal levels at the later stages. $\mathrm{ET}_{\mathrm{B}}$ receptor binding affinity and density, on the other hand, are not altered in the first $24 \mathrm{~h}$, but significantly increase by 7 days of permanent cerebral ischemia, indicating the role these receptors may play in the recovery of the brain following ischemic stroke. We speculate that following cerebral ischemia in the initial phase antagonism of $\mathrm{ET}_{\mathrm{A}}$ receptors and in the later stage stimulation of $\mathrm{ET}_{\mathrm{B}}$ receptors may prove to be beneficial.

\section{Conflict of interest}

\section{$\nabla$}

The authors have no conflict of interest to disclose.

\section{References}

1 Franceschini R, Gandolfo C, Cataldi A et al. Twenty-four-hour endothelin-1 secretory pattern in stroke patients. Biomed Pharmacother 2001; 55: 272-276

2 Leonard MG, Briyal S, Gulati A. Endothelin B receptor agonist, IRL-1620, reduces neurological damage following permanent middle cerebral artery occlusion in rats. Brain Res 2011; 1420: 48-58

3 Kojima T, Isozaki-Fukuda Y, Takedatsu $M$ et al. Circulating levels of endothelin and atrial natriuretic factor during postnatal life. Acta Paediatr 1992; 81: 676-677

4 Levin ER. Endothelins. N Engl J Med 1995; 333: 356-363

5 Schiffrin EL, Intengan HD, Thibault $G$ et al. Clinical significance of endothelin in cardiovascular disease. Curr Opin Cardiol 1997; 12: 354-367
6 Schneider MP, Boesen EI, Pollock DM. Contrasting actions of endothelin ET(A) and ET(B) receptors in cardiovascular disease. Annu Rev Pharmacol Toxicol 2007; 47: 731-759

7 Schinelli S. Pharmacology and physiopathology of the brain endothelin system: an overview. Curr Med Chem 2006; 13: 627-638

8 Barone FC, Ohlstein EH, Hunter AJ et al. Selective antagonism of endothelin-A-receptors improves outcome in both head trauma and focal stroke in rat. J Cardiovasc Pharmacol 2000; 36: S357-S361

9 Briyal S, Gulati A. Endothelin-A receptor antagonist BQ123 potentiates acetaminophen induced hypothermia and reduces infarction following focal cerebral ischemia in rats. Eur J Pharmacol 2010; 644: 73-79

10 Gupta SK, Saxena A, Singh $U$ et al. Bosentan, the mixed ETA-ETB endothelin receptor antagonist, attenuated oxidative stress after experimental myocardial ischemia and reperfusion. Mol Cell Biochem 2005; 275: 67-74

11 Moldes 0 , Sobrino T, Blanco $M$ et al. Neuroprotection afforded by antagonists of endothelin-1 receptors in experimental stroke. Neuropharmacology 2012; 63: 1279-1285

12 Zhang Y, Belayev L, Zhao W et al. A selective endothelin ET(A) receptor antagonist, SB 234551, improves cerebral perfusion following permanent focal cerebral ischemia in rats. Brain Res 2005; 1045: 150-156

13 Leonard MG, Briyal S, Gulati A. Endothelin B receptor agonist, IRL-1620, provides long-term neuroprotection in cerebral ischemia in rats. Brain Res 2012; 1464: 14-23

14 Leonard MG, Gulati A. Endothelin B receptor agonist, IRL-1620, enhances angiogenesis and neurogenesis following cerebral ischemia in rats. Brain Res 2013; 1528: 28-41

15 Koizumi J, Yoshida Y, Nakazawa $T$ et al. Experimental studies of ischemic brain edema. I. A new experimental model of cerebral embolism in rats in which recirculation can be introduced in the ischemic area. Jpn J Stroke 1986; 8: 1-8

16 Tatlisumak T, Carano RA, Takano $\mathrm{K}$ et al. A novel endothelin antagonist, A-127722, attenuates ischemic lesion size in rats with temporary middle cerebral artery occlusion: a diffusion and perfusion MRI study. Stroke 1998; 29: 850-857 discussion 857-858

17 Moran PM, Higgins LS, Cordell B et al. Age-related learning deficits in transgenic mice expressing the 751-amino acid isoform of human beta-amyloid precursor protein. Proc Natl Acad Sci USA 1995; 92: 5341-5345

18 Markgraf CG, Green EJ, Hurwitz BE et al. Sensorimotor and cognitive consequences of middle cerebral artery occlusion in rats. Brain Res 1992; 575: 238-246

19 Rogers DC, Campbell CA, Stretton JL et al. Correlation between motor impairment and infarct volume after permanent and transient middle cerebral artery occlusion in the rat. Stroke 1997; 28: 2060-2065 discussion 2066

20 Li F, Irie K, Anwer MS et al. Delayed triphenyltetrazolium chloride staining remains useful for evaluating cerebral infarct volume in a rat stroke model. J Cereb Blood Flow Metab 1997; 17: 1132-1135

21 Barone FC, White RF, Elliott JD et al. The endothelin receptor antagonist SB 217242 reduces cerebral focal ischemic brain injury. J Cardiovasc Pharmacol 1995; 26: (Suppl 3): S404-S407

22 Castillo-Pichardo L, Dharmawardhane SF. Grape polyphenols inhibit Akt/mammalian target of rapamycin signaling and potentiate the effects of gefitinib in breast cancer. Nutr Cancer 2012; 64: 1058-1069

23 Harada $N$, Himeno A, Shigematsu $K$ et al. Endothelin-1 binding to endothelin receptors in the rat anterior pituitary gland: possible formation of an ETA-ETB receptor heterodimer. Cell Mol Neurobiol 2002; 22: $207-226$

24 Lowry OH, Rosebrough NJ, Farr AL et al. Protein measurement with the Folin phenol reagent. J Biol Chem 1951; 193: 265-275

25 Kanekar SG, Zacharia T, Roller R. Imaging of stroke: part 2, pathophysiology at the molecular and cellular levels and corresponding imaging changes. AJR Am J Roentgenol 2012; 198: 63-74

26 Lakhan SE, Kirchgessner A, Hofer M. Inflammatory mechanisms in ischemic stroke: therapeutic approaches. J Transl Med 2009; 7: 97

27 Minger SL, Ekonomou A, Carta EM et al. Endogenous neurogenesis in the human brain following cerebral infarction. Regen Med 2007; 2: 69-74

28 Kaundal RK, Deshpande TA, Gulati A et al. Targeting endothelin receptors for pharmacotherapy of ischemic stroke: current scenario and future perspectives. Drug Discov Today 2012; 17: 793-804

29 Dai X, Galligan JJ. Differential trafficking and desensitization of human ET(A) and ET(B) receptors expressed in HEK 293 cells. Exp Biol Med (Maywood) 2006; 231: 746-751 